\title{
Uptake and reversibility of uptake of nickel by human macrophages
}

\author{
D.L. EDWARDS, J.C. WATAHA* \& C.T. HANKS University of Michigan School of Dentistry, \\ Ann Arbor, Michigan and *Department of Oral Rehabilitation, Medical College of Georgia School of Dentistry, Augusta, Georgia, U.S.A.
}

SUMMARY The use of nickel-containing alloys in dentistry has been questioned because of the biological liabilities of nickel and the release of nickel ions from dental appliances into the oral cavity. The uptake of nickel by cellsin the oral tissues is a critical factor in assessing the biological liabilities of nickel. Nickel uptake by macrophages may be particularly important because of thecentral role of macrophages in the inflammatory process and the known role of the macrophage in orchestrating the response to biomaterials. The aims of the current study were to assess the reversibility of the uptake of nickel from human macrophages and determine the portion of the nickel which reaches the nuclei as a function of time. Cellular nickel content was measured by means of atomic absorption spectrometry. Nuclear nickel content was assessed after fractionating cells. The results showed that nickel was rapidly taken up by macrophages and that the nickel accumulated in the nucleus in as little as $8 \mathrm{~h}$. After $48 \mathrm{~h}$, over $60 \%$ of the cellular nickel was in the nucleus. Once taken up, the nickel was lost at a lower rate. The rate of loss decreased as the initial exposure time to the nickel increased. Thus, the results indicated that macrophages may accumulate nickel if the time between exposures is insufficient to reverse the uptake. Further studies are necessary to correlate the retention of nickel with impaired function of macrophages and to further define the biological risks of using nickel in dental alloys.

\section{Introduction}

Nickel-containing alloys have become common in dental applications. These alloys, which include the stainless steels, are used for crowns, partial denture frameworks, and orthodontic wires and appliances (Craig, 1993). The use of nickel-containing alloys has increased because of their low cost and excellent mechanical properties (Craig, 1993). The amount of nickel in these alloys ranges from $8 \%$ by weight in the stainless steels to $81 \%$ by weight in some partial denture and crown applications (Moffa, 1982).

The use of nickel-containing alloys in dentistry has been questioned because of the biological liabilities of nickel and the release of nickel ions from dental appliances into the oral cavity (Moffa, 1982; Mjör \&
Hensten-Pettersen, 1983; Black, 1984; Black, 1988). Nickel is a well-documented allergen (Moffa, 1982; Hildebrand, Veron \& Martin, 1989; Goyer, 1986), carcinogen in the subsulphide form $\left(\mathrm{Ni}_{3} \mathrm{~S}_{2}\right)$ (Coogan et al., 1989; Costa, 1989; Costa, 1991), and environmental toxin (Doll, 1984). The release of nickel ions from nickel-containing alloys in biomedical applicationshas been measured in vitro (Muller, Maessen \& Davidson, 1990; Gerstorfer, Sauer \& Pässler, 1991; Tai et al., 1992) and in vivo (Black et al., 1983; Woodman, Black \& Nunamaker, 1983; Trainsnel et al., 1990). The concentrations of nickel ions in tissues around implanted alloys has been measured as high as $123 \mu \mathrm{g} / \mathrm{mL}$ (normal $\leqslant 2 \mu \mathrm{g} / \mathrm{mL}$ ) (Bergman, Bergman \& Söremark, 1980), but the release is dependent on $\mathrm{pH}$ and application (Muller et al., 1990). In vivo, nickel 
concentrations have risen from $0 \cdot 7-2.5 \mathrm{ng} / \mathrm{mg}$ of serum after implantation of a nickel-containing finger joint prosthesis for 12 months in cats (Woodman et al., 1983). Since nickel is released into the body, the uptake and reversibility of uptake of nickel by cells is a central issue to the biological liability of such release. If nickel is taken up by cells, the risk of biological effects increases and if the uptake is irreversible, then the potential for accumulation to harmful levels in cells increases. Nickel uptake by macrophages may be particularly important because of the central role of macrophages in the inflammatory process (Auger \& Ross, 1992) and the known role of the macrophage in orchestrating the response to biomaterials (Anderson \& Miller, 1984). In dental applications, nickel-containing alloys are often in close proximity to the gingival tissues where macrophages are known to play an important role in the maintenance of the periodontal tissues (Page, 1991). The uptake of nickel by cells has been investigated for T cells, B cells, erythrocytes, macrophages and fibroblasts (Webb \& Weinzierl, 1972; Nieboer et al., 1984; Nordlind, 1985; Menon \& Nieboer, 1986). Organic ligands limited or enhanced the uptake of $\mathrm{Ni}$ ions by macrophages or lymphocytes and accelerated or prevented the removal of $\mathrm{Ni}$ from these cells once taken up (Nieboer et al., 1984; Menon \& Nieboer, 1986). Compounds which form lipophilic complexes appeared to favour cell uptake and retention. However, T cells from individuals who were hypersensitive to nickel were no more prone to nickel uptake than those from unsensitized individuals (Nordlind, 1985; Menon \& Nieboer, 1986). In mouse fibroblasts, the rate of nickel uptake was 0.043 femtomoles/cell per hour, which was low among eight metal ions which were tested (range was $0.012{\mathrm{for} \mathrm{Pd}^{2+}}^{2+}$ to $>8.0$ for $\mathrm{In}^{3+}$ ) (Wataha, Hanks \& Craig, 1993). Additionally, the nickel which was taken up by fibroblasts was not reversible at the same rate. Sixty per cent of the $\mathrm{Ni}$ ions taken up after $2 \mathrm{~h}$ remained in the cell $5 \mathrm{~h}$ after the nickel ions were removed from the medium. When the initial exposure time was increased to $6 \mathrm{~h}, 72 \%$ of the Ni remained after $5 \mathrm{~h}$ of reversal time (Wataha et al., 1993). Thus, in fibroblasts the uptake rate of nickel was greater than the release rate, and the release rate slowed as the time of initial exposure increased.

The intracellular distribution of nickel into cells has also been investigated to some extent. In fibroblasts, ${ }^{63} \mathrm{Ni}^{2+}$ was distributed among all subcellular fractions, but primarily in the nuclei (Webb \& Weinzierl, 1972).
Nuclear accumulation of nickel has also been reported for human blood lymphocytes and rabbit alveolar macrophages (Nordlind, 1985; Nieboer et al., 1984). The presence of nickel in the nuclei appears to have functional importance as well, as it has been shown to alter secretion of cytokines from macrophages (Wataha, Hanks \& Sun, 1995; Wataha etal., 1997) and DNA synthesis of lymphocytes (Nieboer et al., 1984).

The hypothesis of the present study was that the time of exposure of nickel to macrophages is important in the reversibility of nickel uptake and the distribution into the nucleus. Since dental alloys may release nickel ions for short bursts following initial insertion or disruption of passivating surfaces, the factor of time is critical to the biological liability of these alloys. The specific aims of the study were to establish (i) the reversibility of nickel uptake by macrophages and (ii) distribution of nickel into nuclei, both as a function of time. This information will help define the risks of using nickel-containing dental alloys and other biomedical alloys containing nickel.

\section{Materials and methods}

The cells used were human THP-1 monocytesmacrophages*. They were grown in suspension in RPM I $1640^{\dagger}$ with $10 \%$ fetal bovine serum ${ }^{\dagger}, \beta$ mercaptoethanol $^{\ddagger}(50 \mu \mathrm{moL} / \mathrm{l})$, penicillin ${ }^{\dagger}$ (100 units/ $\mathrm{mL}$ ), and streptomycin ${ }^{\dagger}(1001 \mathrm{~g} / \mathrm{mL})$. Cells were plated at 45000 cells $/ \mathrm{mL}$ and allowed to grow for 7 days to approximately 700000 cells $/ \mathrm{mL}$ in $15 \mathrm{~mL}$ before exposure to nickel ions. Population doubling time of the cells was measured to be $43 \mathrm{~h}$.

Nickel ions from $\mathrm{NiCl}_{2} \cdot 6 \mathrm{H}_{2} \mathrm{O}^{\text {§ }}$ were added to the cells from an aqueous solution. Fifty microlitres were added to each flask containing $15 \mathrm{~mL}$ of cell suspension to give a final nickel concentration of $10 \mu \mathrm{g} / \mathrm{mL}$ $(170 \mu \mathrm{mol} / \mathrm{L})$. This concentration was selected on the basis of pilot experiments which showed that the cells would not be lysed by this concentration after $48 \mathrm{~h}$ exposure. Water was added to the control cultures. In initial experiments, the exposure times ranged from 8 to $48 \mathrm{~h}$, but exposures greater than $8 \mathrm{~h}$ made the cells too fragile to process for $\mathrm{Ni}$ content. Therefore, the

*ATCC \#IIB 202; Rockville, MD, U.S.A.

${ }^{\dagger}$ Gibco BRL, Gaithersburg, MD, U.S.A.

‡Sigma, St. Louis, MO, U.S.A.

§Aldrich, Milwaukee, WI, U.S.A 
exposure times were shortened to 2-8 $\mathrm{h}$. The cells were counted in a haemocytometer before and after addition of the nickel. After nickel exposure, the cells were washed five times with $5 \mathrm{~mL}$ of phosphate-buffered saline. Centrifugation at $600 \times \mathrm{g}$ for $10 \mathrm{~min}$ was used to isolate the cells between washes. The cells were counted again after the last wash to ensure that cells were not lost during the washing procedure. Water $(1.5 \mathrm{~mL})$ was added to the last cell pellet, and the resulting suspension was treated ultrasonically for $30 \mathrm{~s}$, then assayed for nickel content by means of atomic absorption spectroscopy (Wataha, Craig \& Hanks, 1991). To measure reversibility of the nickel uptake, nickel was removed from the cultures after the initial exposure and fresh medium without nickel was added for 4$48 \mathrm{~h}$, after which the cells were processed for nickel content as previously described. Nickel content was calculated as pg/cell based on cell counts and the atomic absorption measurements. The detection limit for nickel was $0.0015 \mathrm{pg}$ of nickel per cell. The solutions used to process the cells such as medium and saline had no detectable nickel (detection limit was $0.020 \mu \mathrm{g} / \mathrm{mL}$ ).

To determine the distribution of nickel into the cell nuclei, the cells were centrifuged, the medium was removed, and 0.1\% NP40 in phosphate-buffered saline ${ }^{\ddagger}$ was added for $5 \mathrm{~min}$ to isolate the nuclei. The nuclei preparation was verified by microscopy, the ability of the preparation to take up propidium iodide (assessed by fluorescence microscopy), and the absence of mitochondria (lack of MTT staining). Nuclei were washed with phosphate-buffered saline and isolated by centrifugation at $600 \times$ g for $10 \mathrm{~min}$, after which $1.5 \mathrm{~mL}$ of water wasadded to the pellet and ultrasonic treatment was used to disperse the pellet. The nickel content was measured and the nickel content per nucleus was calculated as previously described. The nuclear nickel content was compared to parallel preparations of whole cells, and the percentage of nickel in the nuclei was calculated.

\section{Results}

Nickel ions were rapidly taken up into the macrophages over the first $4 \mathrm{~h}$ of exposure, after which the uptake levelled off at about $0.023 \mathrm{pg} / \mathrm{cell}$ (Fig. 1). The rate of reversal of nickel uptake depended on the initial exposure time (Fig. 2). After $2 \mathrm{~h}$ initial exposure, the cellular nickel dropped significantly within $4 \mathrm{~h}$ of reversal time, and was essentially complete after $24 \mathrm{~h}$.

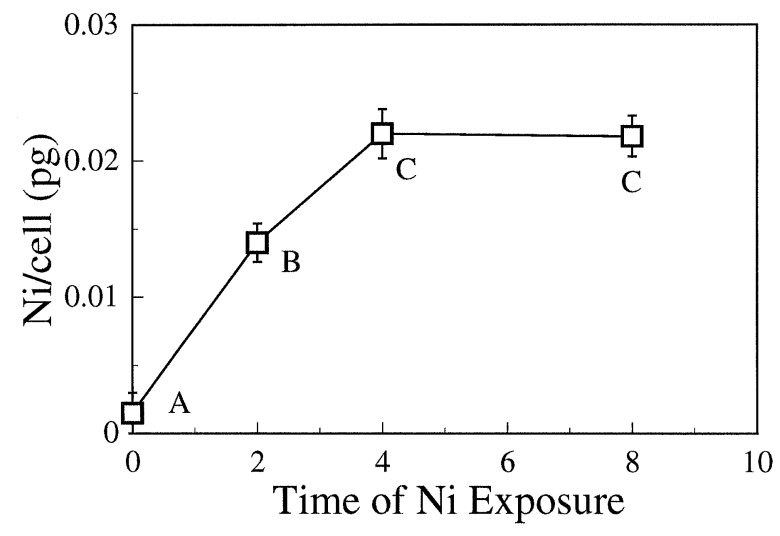

Fig. 1. Macrophages were exposed to nickel ions for 2,4 , or $8 \mathrm{~h}$ after which unbound nickel was washed away and retained nickel measured. Detection limit for the assay was $0.0015 \mathrm{pg} / \mathrm{cell}$. Controls were $0 \mathrm{~h}$ readings without the addition of nickel to the cultures. Error bars indicate standard deviations of $n=3$. Different capital letters indicate statistical differences (ANOVA, Scheffe comparison intervals, $\alpha=0.05$ ).

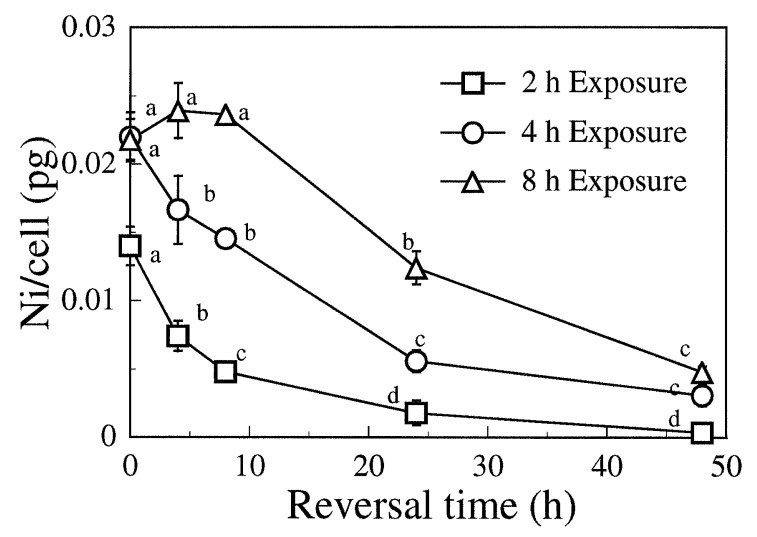

Fig. 2. Macrophages were exposed to nickel ions for 2,4 , or $8 \mathrm{~h}$. After washing, the cells were incubated without nickel for 8-48 h, after which nickel which was retained in the cells was measured. Results are expressed in pg of nickel per cell. The detection limit for the assay was $0.0015 \mathrm{pg} /$ cell; error bars indicate standard deviations for $n=3$. Control cells did not contain detectable amounts of nickel. For each line, different letters indicate different statistical groups (ANOVA, Scheffe comparison intervals, $\alpha=0.05$ ).

After $48 \mathrm{~h}$ of reversal time, approximately $3 \%$ of the original nickel was still present in the cells. When the initial exposure time was increased to $4 \mathrm{~h}$, a similar pattern of reversal occurred, but at $48 \mathrm{~h}, 14 \%$ of the original nickel in the cells remained. When the initial exposure was $8 \mathrm{~h}$, the pattern of loss changed significantly. No nickel was lost from the cells for at least $8 \mathrm{~h}$, after which a gradual loss occurred. However, at $48 \mathrm{~h}, 22 \%$ of the original nickel remained per cell. The loss of nickel from the cells was complicated by the 


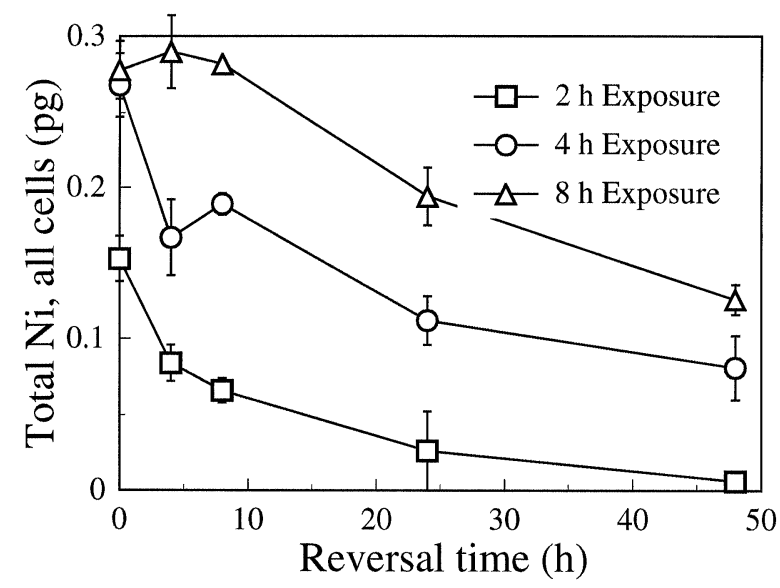

Fig. 3. Results are similar to those in Fig. 2, but are expressed as total nickel retained by the culture as a function of reversal time. This figure accounts for the increase in cell number during the reversal time. The detection limit for the assay was $0.0015 \mathrm{pg} /$ cell; error bars indicate standard deviations for $n=3$. Control cells did not contain detectable amounts of nickel. Statistical groups were identical to those in Fig. 2.

increased number of cells from growth during the period of reversal. Cell division during the reversal time tended to 'dilute' the amount of $\mathrm{Ni}$ per cell. If the increase in cells during the reversal time was accounted for, then the actual loss of nickel at $48 \mathrm{~h}$ was $96 \%$ after $2 \mathrm{~h}$ initial exposure, $70 \%$ after $4 \mathrm{~h}$, and $55 \%$ after $8 \mathrm{~h}$ (Fig. 3). Thus, the actual reversibility of the nickel uptake was less than indicated in Fig. 2. The pattern of nickel loss was similar in Figs 2 and 3, but the nickel remaining in the cells after $48 \mathrm{~h}$ was different because of the change in total cell number during the period of reversal.

The amount of nickel which reached the nuclei of the cells increased as the time of exposure increased from 8 to 48 h (Fig. 4). After 48 h, $60 \%$ of the nickel in the whole cells were associated with the nuclei (Fig. 5). The increase in nuclear nickel content was significantly greater at each time of exposure (ANOVA).

\section{Discussion}

The current study confirmed the intercellular penetration of nickel ions. This result agrees with those of previous investigators who have studied the subcellular distribution of nickel (Webb \& Weinzierl, 1972; Nieboer et al., 1984; Menon \& Nieboer, 1986). The current study also showed that the movement from the extracellular spaces to the nuclear compartment was rapid. After $8 \mathrm{~h}, 25 \%$ of the cellular nickel was in

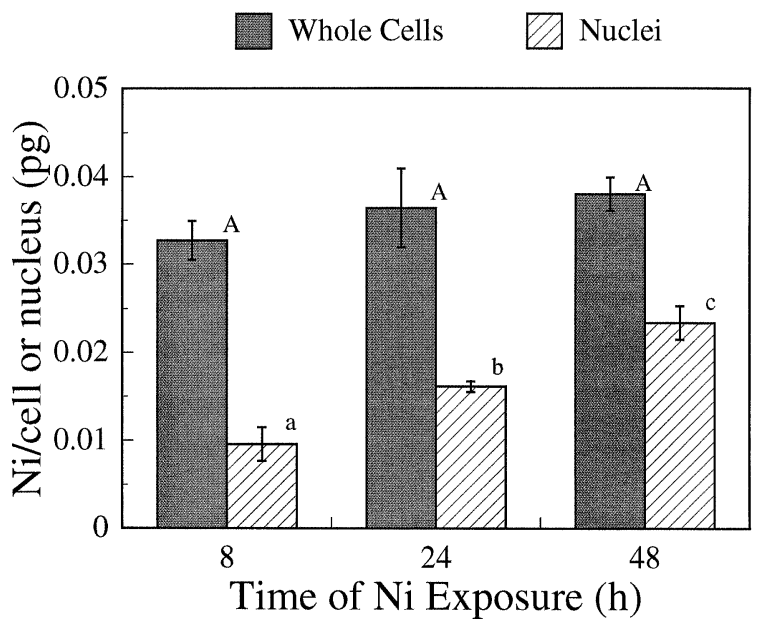

Fig. 4. Macrophages were exposed to nickel ions for 8,24 , and $48 \mathrm{~h}$. Cells were then separated into two groups. One group was analysed for whole cell nickel content, and one for nickel content in the nuclei. The detection limit for the assay was $0.0015 \mathrm{pg} /$ cell; error bars indicate standard deviations for $\mathrm{n}=3$. Control cells did not contain detectable amounts of nickel. For each set of columns, different letters indicate different statistical groups (ANOVA, Scheffe comparison intervals, $\alpha=0.05$ ).

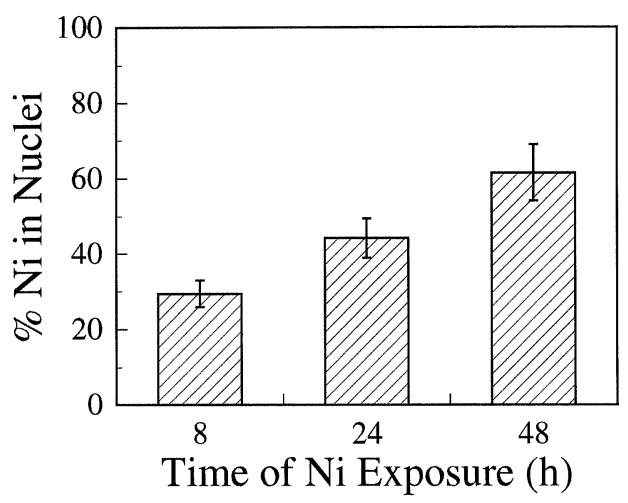

Fig. 5. The percentage of total cellular nickel retained by the nucleus as a function of exposure time. All groupswere statistically different from one another (ANOVA, Scheffe comparison intervals, $\alpha=0.05)$.

the nucleus (Figs 4, 5). Thus, although the mechanism of uptake of nickel was not determined, any uptake mechanisms must account for this rapid uptake. At $48 \mathrm{~h}$, the nuclei contained more than $60 \%$ of the nickel. Therefore, it appeared from the current study that there was a tendency for nickel ions to accumulate in the nucleus of these macrophages with time. After $48 \mathrm{~h}$, the concentration of nickel in the nuclei of macrophages was substantially higher than that seen by Webb \& Weinzierl (1972) in fibroblasts (36\%). This difference may reflect differences in passive diffusion of nickel 
through the different cellular architectures, or may indicate differences in active transport of nickel.

Increasing the initial time of nickel exposure significantly slowed the loss of nickel from the cells (Figs 2, 3). Even when the initial uptake of nickel was equivalent at two exposure times, the longer exposure time resulted in a prolonged retention of nickel by the cells (Fig. 2). Thus, the longer retention was not simply a function of the increased nickel per cell with time, but must have been also a function of the distribution and binding of nickel. The observation that increased exposure times led to increased nuclear concentration (Fig. 4) supports this idea. It is likely that all binding sites for nickel are not of equal affinity, and it may be that over the time of exposure, the nickel tends to accumulate in the higher affinity binding sites. If this idea is true, then the nucleus would appear to be a higher affinity binding site since nickel accumulated there with time (Figs 4 and 5). Further studies should examine the reversibility of binding from subcellular fractions as well as whole cells.

The relationship of the external concentration of nickel to the rate of its uptake is critical to the in vivo risks that nickel poses. If high external concentrations lead to higher uptake rates, then cellular toxicity may develop more quickly because of the higher intracellular concentrations, and reversibility may be secondary because the cells die. The current study did not address the effect of the external concentration of nickel on its distribution and reversibility of uptake. However, previous studies with fibroblasts have shown that the rate of nickel uptake increases linearly with increases in external concentration (Wataha et al., 1993). The fibroblasts are probably not representative of the macrophages used in the current study since the fibroblasts did not saturate with nickel over the $8 \mathrm{~h}$ uptake period (Wataha, Hanks \& Craig, 1994). Macrophages used in the current study showed cellular saturation after only $4 \mathrm{~h}$ (Fig. 1).

The rate of nickel uptake by the macrophages was substantially lower than that seen with fibroblasts in other studies (Webb \& Weinzierl, 1972; Wataha et al., 1993). Previous work with Balb/c mouse fibroblasts (Wataha et al., 1993) showed that $\mathrm{Ni}$ reached about $0.32 \mathrm{pg} /$ cell after only $6 \mathrm{~h}$ whereas the macrophages in the current study reached just over $0.02 \mathrm{pg} /$ cell after $8 \mathrm{~h}$. Some of this difference may reflect the smaller size of the macrophages. The pattern of uptake in macrophages was also different from fibroblasts, which showed linear uptake with time for at least $8 \mathrm{~h}$ (Wataha et al., 1993) and up to $24 \mathrm{~h}$ (Webb \& Weinzierl, 1972) before saturation occurred. Differences in the uptake between cell types indicates that different mechanisms of uptake may occur for different types of cells. Some of these differences may be attributed to the anchorage dependence of the fibroblasts versus the anchorage independence of the macrophages, although no conclusions can be drawn from the current results. In both cell types, the rate of loss of nickel from cells decreased as the time of initial exposure increased.

To summarize, this study has shown that the time of initial exposure is a critical factor in the reversibility of the uptake of nickel into macrophages and the accumulation of nickel in the nucleus. As the time of nickel exposure increases, the loss of nickel from the cell slows and a greater percentage of nickel is present in the nucleus. The results imply that nickel which is released from dental alloys may accumulate in cells such as macrophages if the exposure of cells to $\mathrm{Ni}$ is of sufficient concentration and frequency. Based on previous reports (Bergman et al., 1980; Covington et al., 1985; Gerstorfer et al., 1991) dental alloys are capable of releasing quantities of nickel similar to those used in the current study $(10 \mu \mathrm{g} / \mathrm{mL})$ especially under conditions such as low pH (4.0). Accumulation of nickel may lead to altered cell function in tissues in the oral cavity (Wataha et al., 1994). Further study is necessary to define the risk of using nickel-containing alloys in biomedical applications.

\section{Acknowledgments}

The authors thank the following sponsors of this research: the AADR student fellowship program, Metalor Corporation, the World Gold Council, and the Biocompatibility Group at the Medical College of Georgia

\section{References}

ANDERSON, J .M. \& MILLER, K.M. (1984) Biomaterial biocompatibility and the macrophage. Biomaterials, 5, 5.

Auger, M.J . \& Ross, J.A. (1992) The biology of the macrophage, In: The Macrophage (eds C.E. LEWIS \& J .O. MCGEE), p. 3. Oxford University Press, Oxford.

Bergman, M., Bergman, B. \& Söremark, R. (1980) Tissue accumulation of nickel released due to electrochemical corrosion of nonpreciousdental casting alloys. J ournal of Oral Rehabilitation, 7, 325. 
BLACK, J . (1984) Systemic effects of biomaterials. Biomaterials, 5, 11. BLACK, J. (1988) Does corrosion matter? J ournal of Bone and J oint Surgery, 70-B, 517.

Black, J., Maitin, E.C., Gelman, H. \& Morris, D.M. (1983) Serum concentrations of $\mathrm{Cr}, \mathrm{Co}$, and $\mathrm{Ni}$ after total hip replacement: a six month study. Biomaterials, 4, 160.

Coogan, T.P., LATTA, D.M., Snow, E.T. \& CostA, M. (1989) Toxicity and carcinogenicity of nickel compounds. CRC Critical Reviews in Toxicology, 19, 341.

CostA, M. (1989) Perspectives on the mechanism of nickel carcinogenesis gained from models of in vitro carcinogenesis. Environmental Health Perspectives, 81, 73.

CostA, M. (1991) Molecular mechanisms of nickel carcinogenesis. Annual Reviews in Pharmacology, 31, 321.

Covington, J .S., McBride, M.A., SLagle, W.F. \& Disney, A.L. (1985) Quantitization of nickel and beryllium leakage from base metal casting alloys. J ournal of Prosthetic Dentistry, 54, 127.

CRAIG, R.G. (ed.) (1993) Restorative Dental Materials, Chapter 15. Mosby, St. Louis, MO.

DolL, R. (1984) Nickel exposure: a human health hazard. In: Nickel in the Human Environment (ed. F.W. Sunderman), p. 3. Oxford University Press, Oxford.

Gerstorfer, J .G., SAUER, K.H. \& PÄssLeR, K. (1991) Ion release from $\mathrm{Ni}-\mathrm{Cr}-\mathrm{Mo}$ and $\mathrm{Co}-\mathrm{Cr}-\mathrm{Mo}$ casting alloys. International J ournal of Prosthodontics, 4, 152.

GOYER, R.A. (1986) Toxic effects of metals, In: Casarett and Doull's Toxicology (eds C.D. Klaassen, M.O. Amdur \& J. Doull), 3rd edn, pp. 582-635. Macmillan Pub. Co., New York.

Hildebrand, H.F., Veron, C. \& Martin, P. (1989) Nickel, chromium, cobalt dental alloys and allergic reactions: an overview. Biomaterials, 10, 545.

Menon, C.R. \& Nieboer, E. (1986) Uptake of nickel (II) by human peripheral mononuclear leukocytes. Journal of Inorganic Biochemistry, 28, 217.

MJÖR, I.A. \& Hensten-Petersen, A. (1983) The biological compatibility of alternative alloys. International Dental J ournal, 33, 35.

Moffa, J. (1982) Biological effects of nickel-containing dental alloys. J ournal of the American Dental Association, 104, 501.

Muller, A.W.J., Maessen, F.J.M.J. \& DAvidson, C.L. (1990) Determination of the corrosion rates of six dental NiCrMo alloys in an artificial saliva by chemical analysis of the medium using ICP-AES. Dental Materials, 6, 63.
Nieboer, E., Stafford, A.R., Evans, S.L. \& Dolovich, J. (1984) Cellular binding and/or uptake of nickel (II) ions, In: Nickel in the Human Environment (ed. F.W. Sunderman), p. 321. Oxford University Press, Oxford.

NoRDLIND, K. (1985) Nickel binding and uptake in thymocytes and peripheral blood lymphocytes and nickel-allergic and control subjects. International Archives of Allergy Applied to Immunity, 78, 364.

PAGE, R.C. (1991) The role of inflammatory mediators in the pathogenesis of periodontal disease. Journal of Periodontal Research, 26, 230.

Tal, Y., Delong, R., Goodkind, R.J. \& Douglas, W.H. (1992) Leaching of nickel, chromium, and beryllium ions from base metal alloy in an artificial oral environment. J ournal of Prosthetic Dentistry, 68, 692.

Trainsnel, M., Lemaguer, D., Hildebrand, H.F. \& Iost, A. (1990) Corrosion of surgical implants. Clinical Materials, 5, 309.

Wataha, J.C., Craig, R.G. \& Hanks, C.T. (1991) The release of elements of dental casting alloys into cell-culture medium. J ournal of Dental Research, 70, 1014.

WATAHA, J.C., Hanks, C.T. \& CRAIG, R.G. (1993) Uptake of metal cations by fibroblasts in vitro. Journal of Biomedical Materials Research, 27, 227.

WATAHA, J.C., HANKS, C.T. \& CRAIG, R.G. (1994) In vitro effects of metal ions on cellular metabolism and the correlation between these effects and the uptake of the ions. J ournal of Biomedical Materials Research, 28, 427.

WATAHA, J.C., HANKS, C.T. \& SUN, ZL. (1995) In vitro reaction of marophages to metal ions from dental biomaterials. Dental Materials, 11, 239.

WATAHA, J.C., Sun, Z.L., HANKS, C.T. \& FANG, D.N. (1997) Effect of $\mathrm{Ni}$ ions on expression of intercellular adhesion molecule- 1 by endothelial cells. J ournal of Biomedical Materials Research, 36, 145.

WebB, M. \& WeINZIERL, S.M. (1972) Uptake of $63 \mathrm{Ni}^{2+}$ and its complexes with proteins and other ligands by mouse dermal fibroblasts in vitro. British J ournal of Cancer, 26, 292.

Woodman, J.L., Black, J. \& Nunamaker, D.M. (1983) Release of cobalt and nickel from a new total finger joint prothesis made of vitallium. J ournal of Biomedical Materials Research, 17, 655.

Correspondence: John C. Wataha, Department of Oral Rehabilitation, Medical College of Georgia School of Dentistry, Augusta, GA 30912-1260, U.S.A. 